\title{
Ivorian and Ghanaian upwelling comparison: intensity and impact on phytoplankton biomass
}

\author{
Éric Valère Djagoua $^{1 *}$, Jean Baptiste Kassi ${ }^{1}$, Brice Mobio ${ }^{1}$, Jeanne Maffoué Kouadio ${ }^{1}$, \\ Cassandre Dro ${ }^{1}$, Kouadio Affian ${ }^{1}$ and Bachir Saley ${ }^{1,2}$
}

${ }^{1}$ Centre Universitaire de Recherche et d'application en Télédétection (CURAT), Université de Cocody, 22 BP 801 Abidjan 22, Côte d'Ivoire; *vdjagoua@yahoo.fr ${ }^{2}$ Laboratoire des Sciences et Techniques de l'Eau et de l'Environnement (LSTEE), Université de Cocody, 22 BP 582 Abidjan 22, Côte d'Ivoire.

\begin{abstract}
From satellite images of coastal zones of Cote d'Ivoire and Ghana and a few samples in situ phosphate and nitrate, the relationship between SST, nutrients (phosphate + nitrate) and phytoplankton biomass, characterized by the chlorophyll concentration (CHL), are analyzed in upwelling period. Comparative analysis of upwelling indexes (UI) and productive habitat indexes $(\mathrm{PHI})$ in both marine ecosystems showed that $\mathrm{UI}$ of the Ghanaian marine environment is more intense. Thus this environment has a low PHI compared with that Côte d'Ivoire. The transformation analysis by non-linear regression of the relationship between the nutrients $\left(\mathrm{PO}_{2}\right.$ and $\mathrm{NO}_{3}$ ) and $\mathrm{CHL}$ showed that the high of nutrients causes an increase in chlorophyll concentration in the Ivorian waters (ascending relationship). Unlike, in the Ghanaian waters, we observed that the relationship between $\mathrm{CHL}$ and nutrients had a hollow parabolic relationship; which would show a fluctuation of variables in this part of the upwelling central of the Gulf of Guinea.
\end{abstract}

Word Key: Côte d'Ivoire, Ghana, gulf of Guinea, upwelling intensity, biologic productivity

\section{INTRODUCTION}

Coastal areas of the Gulf of Guinea (GG) is a large marine ecosystems that are home to most living marine resources and are the subject of extensive multidisciplinary scientific approach (Sherman et al., 1991). Part of this ecosystem, the coasts of Côte d'Ivoire $(\mathrm{Cl})$ and Ghana (Figure 1), called Central Upwelling of Gulf of Guinea (Hardman-Mountford and McGlade, 2002a), is characterized by upwelling seasonal that differs others upwelling of ocean margins in several respects (Bakun, 1978). Indeed, the link between the wind and the onset of this phenomenon is not highlighted. Moreover, several mechanisms have been proposed to explain its occurrence and the role of the Guinea Current is important (Ingham, 1970) and the presence of capes (Marchal and Picaut, 1977). Ocean waves propagating along the coast are being questioned (Picaut, 1983). Also, the role of local wind does not seem negligible (Colin, 1988). The originality of the Ivorian-Ghanaian upwelling also lies in the existence of two cooling seasons, one primary and one secondary, well differentiated (Arfi et al., 1991 and 1993).

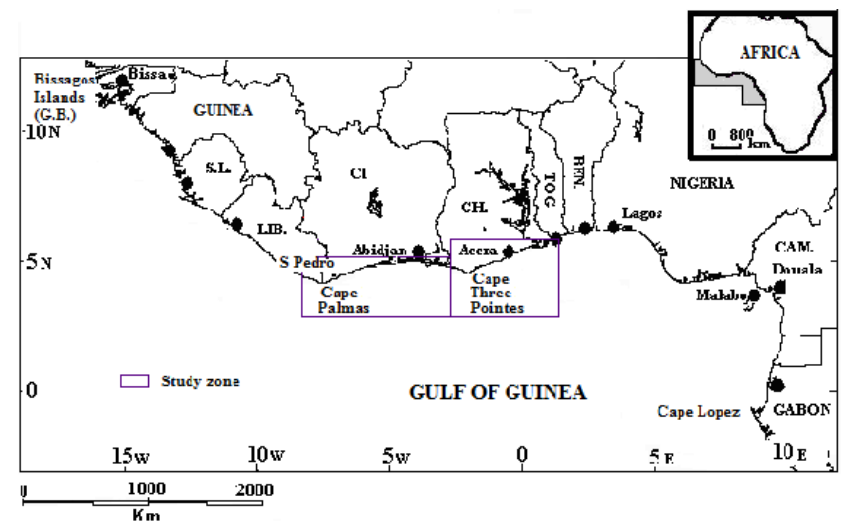

Fig 1. Presentation of the study area (Djagoua et al., 2011, modified) 
Like all coastal upwelling ecosystems, Ivorian and Ghanaian marine supports the development of phytoplankton populations, characterized by the chlorophyll concentration (CHL) (Binet, 1983a and b; Herbland and The Loeuff, 1993, John and al. 2002; Djagoua, 2003, Djagoua et al., 2011). Very few studies using satellite data to follow changes in phytoplankton biomass were conducted. However, the role of upwelling remains delicate. It is in this context that the University Center for Research and Application in Remote Sensing (CURAT) through one of the research areas "knowledge of the Gulf of Guinea by a satellite approach", initiated the study of ocean color, influenced by chlorophyll concentration in both systems (Côte d'Ivoire and Ghana), although having the same seasonal cycle. The main objective of this study is to compare the variation of the upwelling and the influence of the intensity of this phenomenon on the phytoplankton biomass in Ivorian and Ghanaian marine waters using Sea Surface Temperature (SST) and of chlorophyll concentrations [CHL] mainly.

\section{DATA AND METHODOLOGY}

Data: The characterization of the upwelling phenomenon in this part of the Gulf of Guinea will be done by analyzing the Sea Surface Temperatures (SST) from AVHRR/NOAA (http://poet.jpl.nasa.gov/) which are traditional data used to monitor this phenomenon. However, other satellite data and in situ, no less important, will also be used, i.e. chlorophyll [CHL] data (http://reason.gsfc.nasa.gov/Giovanni/) from the SeaWiFS instrument. Nutrients (nitrate and phosphate) data were extracted from the World Ocean Atlas 2009 (WOA09) which is a database of hydrographic National Oceanographic Data Center (NODC,

ftp://ftp.nodc.noaa.gov/pub/data.nodc/woa/WOA09/D ATA). This database includes oceanographic variables interpolated to a set of 33 levels deep "standard" (0, 10, 20, 30, 50, 75, 100, 125, 150, 200, $250,300 \mathrm{~m} . . .1500)$. For this study, the secondary upwelling period (Great Cool Season) which takes place from July to September and characterized by low SST in the two ecosystems is retained. The satellite data are from 2001 to 2004 and in situ data are from August 2001, because the in situ data are rare in the study area.

\section{METHODOLOGY}

To achieve the objective, we performed the synthesis of the SST and [CHL] maps and the calculation of spatial indexes, namely the upwelling index (UI) and the productive habitat index $(\mathrm{PHI})$. We compare the different parameters (SST, CHL and nutrients) with them and apply a transform model to compare and explain the relationships with these variables in the Ivorian-Ghanaian marine ecosystems.

Spatio-temporal synthesis of Sea Surface
Temperatures (TSM) and the [CHL]:
For a spatial and temporal coherence of SST and $[\mathrm{CHL}]$ and to minimize the influence of random variability on patterns of pixels, the images from 2001 to 2004 were summarized monthly. For example, all images from July of four (4) years were averaged to obtain a single image for both the SST and the [CHL].

\section{Calculation of indexes}

Calculation of the Upwelling Index (UI): Monthly and interannual variation of the upwelling on the continental shelf of Cote d'Ivoire and Ghana is estimated quantitatively by calculating the upwelling intensity for the study period. The upwelling intensity (UI) is calculated by subtracting the surface temperature at $25^{\circ} \mathrm{C}$. The value of $25^{\circ} \mathrm{C}$ was selected based on criteria of Bakun (1978) which found that $25^{\circ} \mathrm{C}$ is the maximum threshold set for the upwelling in the Gulf of Guinea. The values of the sea surface temperature (SST) below $25^{\circ} \mathrm{C}$ have positive values and those above $25^{\circ} \mathrm{C}$ are negative. The continental shelf that has the maximum positive values is considered that having a high upwelling intensity. This intensity is given by the following formula:

$$
\mathrm{UI}=25^{\circ} \mathrm{C}-\mathrm{SST}
$$

Calculation of the Productive Habitat Index (IHP): Our approach follows the definition of Feldman (1986) with regard to productive habitat. According to Feldman, a marine ecosystem is productive when the chlorophyll concentrations in this zone are greater than $1 \mathrm{mg} \cdot \mathrm{m}^{-3}$. Therefore to determine the index for each zone, the value 1 was subtracted from the spatial average chlorophyll concentration of the area for each month. An area with positive values IHP will be considered a productive area. The following formula was used:

$$
\mathrm{IHP}=[\mathrm{CHL}]-1 \mathrm{mg} \cdot \mathrm{m}^{-3}
$$

Modeling the parameters: The relationship between SST and CHL being known, we try to show the relationship between $\mathrm{CHL}$ and [Nutrients] and between [Nutrients] and SST. If these relationships are random, a modeling of these variables will be considered. And the nonlinear regression method is 
chosen to explain fluctuations in these parameters in each zone of upwelling.

The nonlinear regression has been the subject of several writings. Thus, we will not go into detail in this study.

\section{RESULTS}

Spatial variability of Sea Surface Temperature (SST) and Chlorophyll concentration [CHL]: Figure 2 shows, respectively, the sea surface temperature and chlorophyll concentration maps of the study period. They show a spatial distribution of sea surface temperature and the chlorophyll concentration along the Ivorian-Ghanaian coastline. Regarding the SST (figure 2a), we observe that it decreases (from 24,5 to $23^{\circ} \mathrm{C}$ ) from west to east and from the coast of Côte d'Ivoire to Ghana. It is also observed a gradual increase of temperature (from 24,5 to $25,5^{\circ} \mathrm{C}$ ) from the coast to open-sea. As the chlorophyll concentration, we observe that the concentration is higher $\left(>5 \mathrm{mg} \cdot \mathrm{m}^{-3}\right)$ to the coast and decreases gradually to the open-sea (figure $6 \mathrm{~b}$ ). We can observe the high chlorophyll concentration at the mouth of river.
Sea Surface Tempertaure (SST) (a)
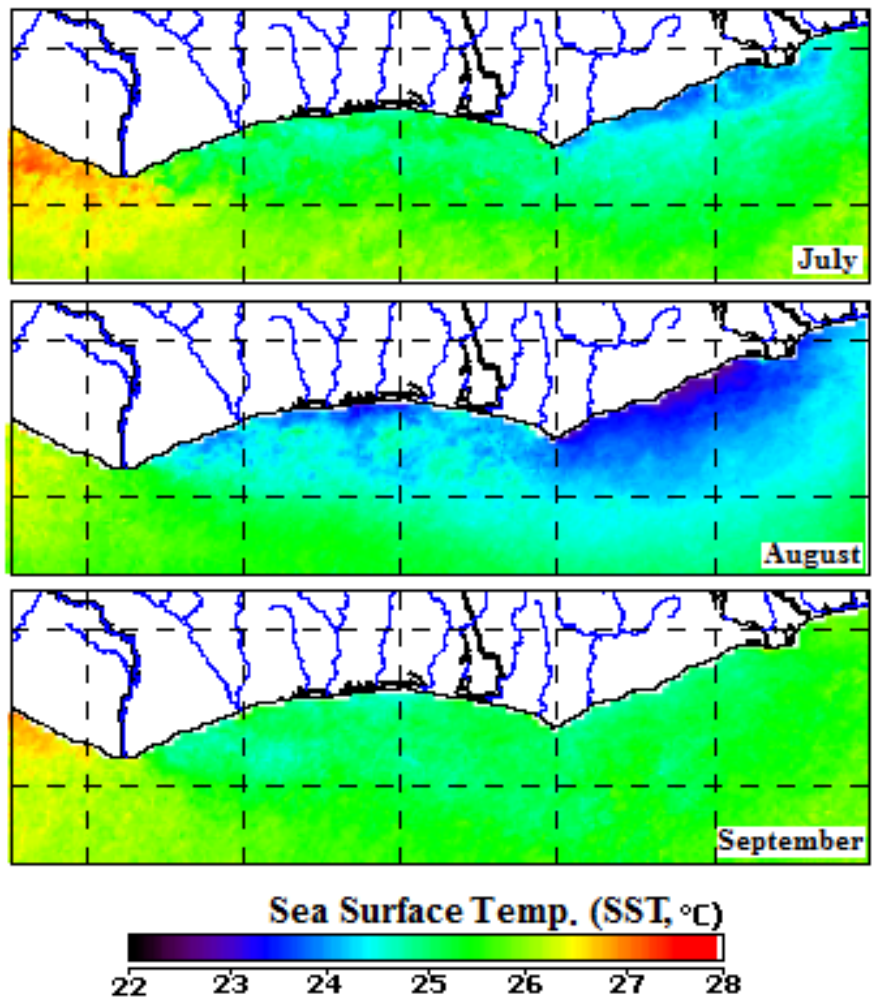

Chlorophyll Concentration [CHL] (b)
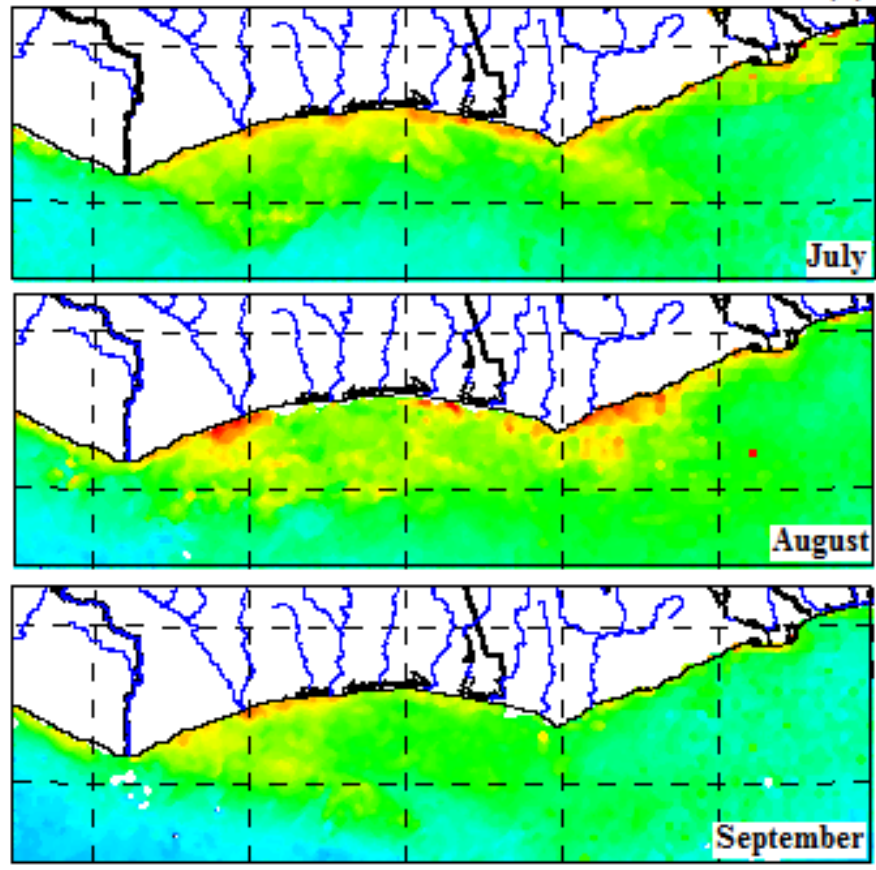

Chlorophyll concent.(mg.m-3)

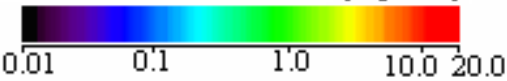

Fig 2. Syntheses Monthly variability of SST and [CHL] concentration from 2001 to 2004.

Upwelling intensity variability : The monthly variability of the intensity in the marine ecosystem in Côte d'Ivoire and Ghana, characterized by the upwelling index is presented in Figure 3. This figure shows that the two curves look the same. In Côte
d'Ivoire, the curve shows that the values encountered during these four years are almost negative, except in August when they are around zero. The lowest intensities are generally observed in July. The average of this intensity in Côte d'Ivoire is $-33^{\circ} \mathrm{C}$. 


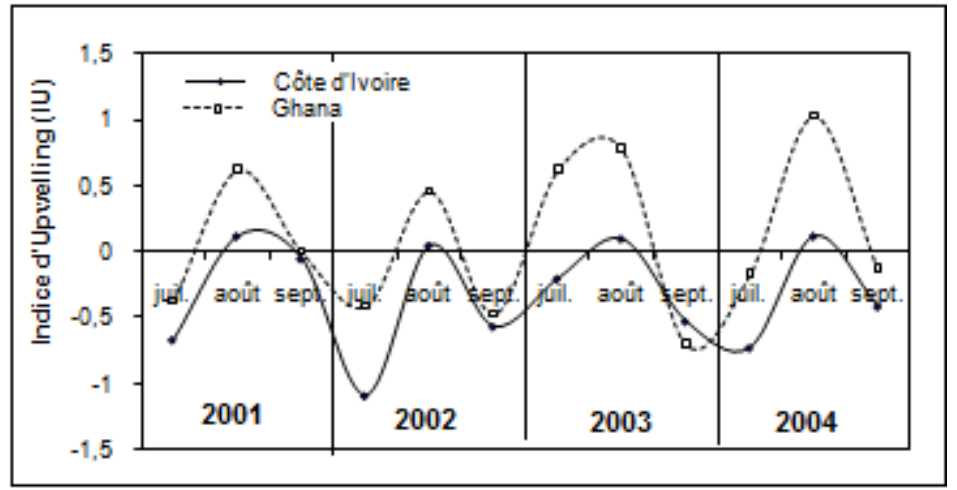

Fig 3. Variability of Upwelling Indexes of Ivorian and Ghanaian marine ecosystems.

The curve of the variation in the upwelling intensity of Ghana shows positive values. There are nevertheless negative values in the month of July in 2001, 2002 and 2003 also in the month of September in 2003 and 2004. August shows high levels $(0,6$ to $1^{\circ} \mathrm{C}$ ). The overall average in Ghana is $0,34^{\circ} \mathrm{C}$.

The shape of the curves of upwelling indexes of these two areas from 2001 to 2004 shows that august is the most cool and july the most warm. This curve shows also that the waters of the continental shelf of Ghana tend to cool gradually while the waters of the continental shelf of Côte d'Ivoire seem warm and stable.

Productive habitat Index (PHI) variability: Figure 4 shows the monthly variability of the productive habit indexes. In general, Côte d'Ivoire has the highest values during the study period and the average is $0,29 \mathrm{mg} \cdot \mathrm{m}^{-3}$. In Ghana, the average is $0,11 \mathrm{mg} \cdot \mathrm{m}^{-3}$.

The PH Indexes for July are substantially identical in 2002 and 2003 for the two continental shelves. By behalf in 2001, the average values show a marked difference; that of Côte d'Ivoire is $0,78 \mathrm{mg} \cdot \mathrm{m}^{-3}$ and that of Ghana is $0,02 \mathrm{mg} \cdot \mathrm{m}^{-3}$. The difference of these two values is $0,76 \mathrm{mg} \cdot \mathrm{m}^{-3}$. The highest productive habitat index $\left(1,0 \mathrm{mg} \cdot \mathrm{m}^{-3}\right)$ in Côte d'Ivoire has met in August 2003. In Ghana, in August, we observe, also, the highest index $\left(0,88 \mathrm{mg} \cdot \mathrm{m}^{-3}\right)$, but in 2002 . The lowest index was observed in September for Côte d'Ivoire $\left(-0,29\right.$ mg. $\left.\mathrm{m}^{-3}\right)$ in 2002 . In Ghana, the lowest values $\left(-0,33 \mathrm{mg} \cdot \mathrm{m}^{-3}\right)$ were also met in September from 2002 to 2004.

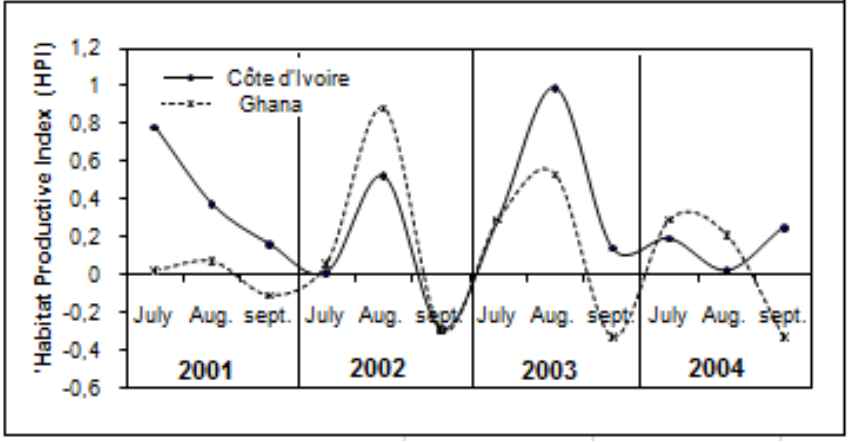

Fig 4. Productive Habitat Indexes variability of Ivorian and Ghanaian marine ecosystems.

Influence of nutrients on the abundance of phytoplankton: The analysis of the upwelling and habitat productive indexes of Côte d'Ivoire and Ghana marine environments shows that the upwelling is more intense at the Ghanaian waters $\left(U I_{\text {moy }}=0,11\right)$ than the Côte d'Ivoire $\left(U I_{\text {moy }}=-0,33\right)$. However, the Ghana marine environment is less productive $\left(\mathrm{IHP}_{\text {moy }}=0,11\right)$ than that of Côte d'Ivoire $\left(\mathrm{HHP}_{\text {moy }}=0,29\right)$.

This finding shows that the high upwelling intensity did not make very productive the Ghana marine ecosystem. So we thought to a contribution of nutrients, particularly phosphate $\left(\mathrm{PO}_{2}\right)$ and nitrate $\left(\mathrm{NO}_{3}\right)$ whose presence is limiting factor in the development of photosynthetic activity of phytoplankton (Dufour and Berland, 1999).

Figure 5 shows the spatial distribution of chlorophyll concentration in relation to the sum of the phosphate and nitrate concentrations and sea surface temperature in Ivorian and Ghanaian marine. It reveals a high content of nutrients at the Ivorian coast but that content isn't high at the Ghanaian coast. The same figure shows that the concentrations are high in the central part of Côte d'Ivoire as well as chlorophyll 
in nutrients. The area affected by blooms of phytoplankton cells is much more extensive. Low concentrations of chlorophyll and nutrients were observed in the Ghanaian side, so that the upwelling is more intense and extends over a larger area.

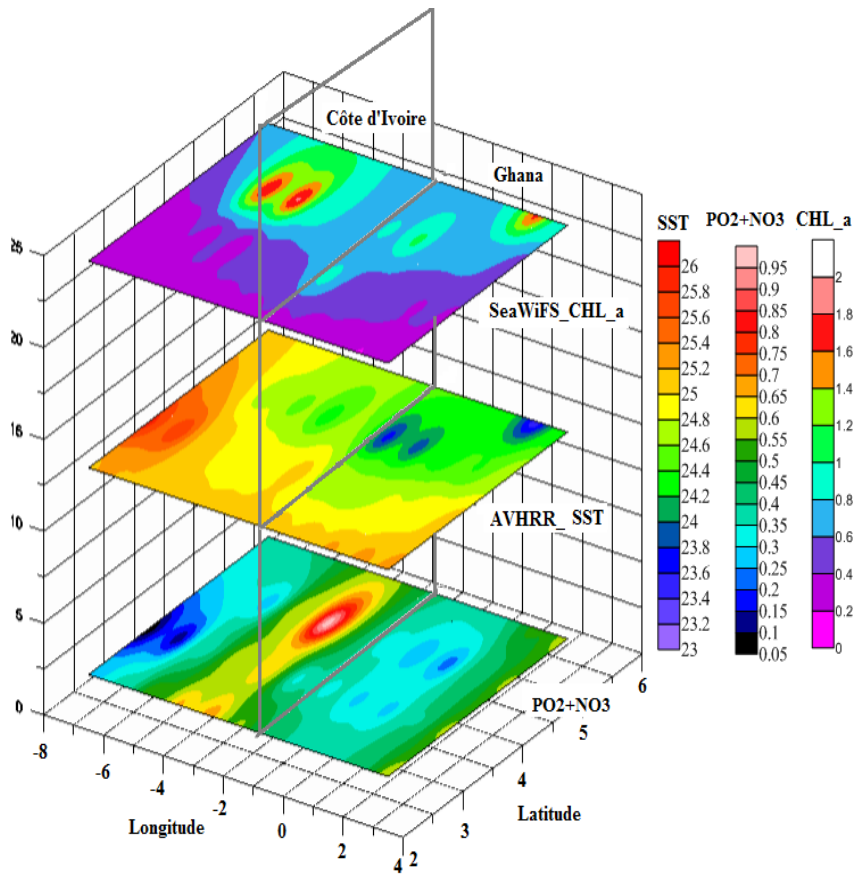

Fig 5. Spatial variability of SeaWiFS chlorophyll concentration, AVHRR Sea Surface Temperature and in situ phosphate $\left(\mathrm{PO}_{2}\right)$ and Nitrate $\left(\mathrm{NO}_{3}\right)$ concentration off Ivorian and Ghanaian upwelling in august 2001.

Estimating and modeling the relationship between chlorophyll concentration, sea surface temperature (SST) and nutrients: The relationship between the content of nutrients $\left(\mathrm{NO}_{3}+\mathrm{PO}_{2}\right)$ and the surface temperature is linear in Côte d'Ivoire. In terms of Ghana, a significant dispersion of points is observed (Fig. 6a), which shows that the relationship between nutrients and $\mathrm{CHL}$ is difficult to interpret. By behalf, at the Ivorian coast, the relationship is linear when the $\mathrm{CHL}$ is less than $0,5 \mathrm{mg} \cdot \mathrm{m}^{-3}$. Beyond this value, the points are scattered (Fig. 6b). This figure shows that the trend of relationship between different parameters seems to be growing in Ghana. In Côte d'Ivoire, the relationship between nutrients and SST is decreasing and between the $\mathrm{CHL}$ and nutrients, the relationship seems to be growing. This analysis differs from those made using conventional regression models or linear relationship between the parameters is fixed priori. The model used provides no information on the form of relationships between variables. This indicates that non-linearity can be demonstrated especially in Ghana.
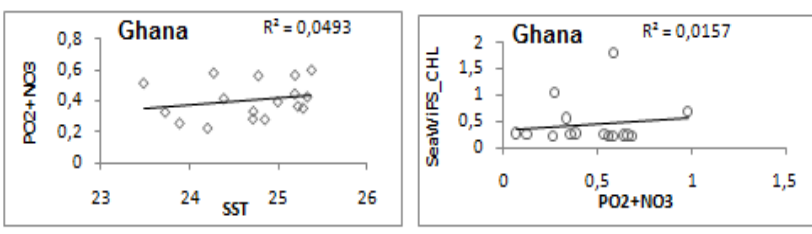

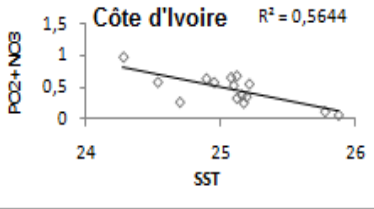

a)

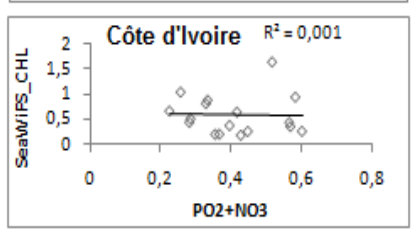

b)
Fig 6. Relationships between nutritive salts (Phosphate and Nitrate) and sea surface temperature (a) and between nutritive salts and chlorophyll concentration (b).

The results of the nonlinear regression model of variables $\mathrm{CHL}$ and nutrients $\left(\mathrm{NO}_{3}+\mathrm{PO}_{2}\right)$, in the relationships $[\mathrm{CHL}]=\mathrm{f}\left(\mathrm{PO}_{2}+\mathrm{NO}_{3}\right)$ and $\left(\mathrm{PO}_{2}+\mathrm{NO}_{3}\right)$ = $\mathrm{f}(\mathrm{TSM})$ (Fig. 7), shows clearly in Côte d'Ivoire, a quasi-linear relationship increasing between the $\mathrm{CHL}$ and nutrients and decreasing between nutrients and TSM (relationship is identical to the conventional). These relations show that the nutrient concentration is, in part, inversely proportional to the surface temperature and the other, proportional to the chlorophyll concentration. In Ghana, by behalf, the transformation of $\mathrm{CHL}$ and nutrient, calculated for relations $[\mathrm{CHL}]=\mathrm{f}\left(\mathrm{PO}_{2}+\mathrm{NO}_{3}\right)$ and $\left(\mathrm{PO}_{2}+\mathrm{NO}_{3}\right)=\mathrm{f}$ (TSM), has a hyperbolic shape with a point low at $24,20^{\circ} \mathrm{C}$ for SST (Fig. 7a) and at $0,48 \mu \mathrm{mol}^{-I^{-1}}$ for nutrients (Fig. 7b). Detailed analysis of these curves shows that:

- for values of surface temperature below $24,20^{\circ} \mathrm{C}$, the relationship between SST and nutrients is inversely proportional; when the SST is above $24,20^{\circ} \mathrm{C}$, the correlation is linear proportionally between the two variables, but with high amplitude (Fig. 7a); - between 0,10 and $0,48 \mu \mathrm{mol} . \mathrm{I}^{-1}$, the relationship between the $\mathrm{CHL}$ and nutrients and is linear and decreasing; for higher values to $0,48 \mu \mathrm{mol}^{-1} \mathrm{I}^{-1}$ (hollow point), the shape of the transform is linear increasing (Figure 7b).

The heterogeneity found in the form of models between the physical and biological parameters in 
Ghanaian ecosystem shows a fluctuating relationship between the contents of nutrients and SST and between nutrients and [CHL] because of the high variability of those environmental parameters in this region of gulf of Guinea.
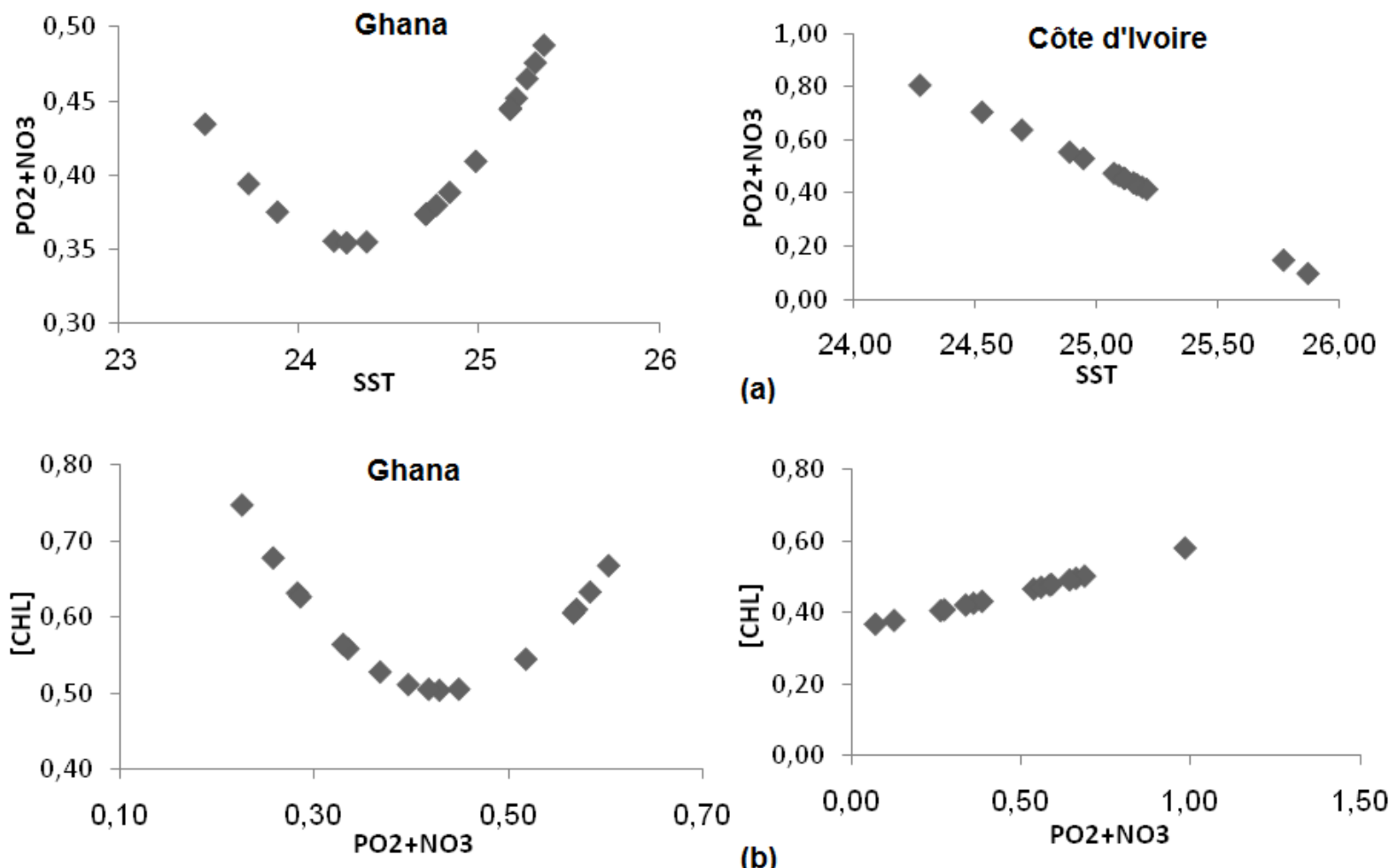

Fig 7. Transformed relationships between nutritive salts and sea surface temperature (a) and between nutritive salts and chlorophyll (b).

\section{DISCUSSION}

The results of analysis of images show that the sea surface temperature is generally higher in western Ivorian coast. Temperature off Côte d'Ivoire decreases when going east. Chlorophyll is rather higher at the coast and decreases offshore. High chlorophyll concentration in 2001, 2003 and 2004 are observed in the West and in 2002 in the East during the study period. As a coastal upwelling occurs in the western part, in the vicinity of Cape Palmas (Morliere, 1977), and the fertile waters reaching the surface are then driven out to open-sea, especially on the east by the Guinea Current, resulting in a skewed distribution of phytoplankton. Poor to the point of emergence ( $<0.40 \mathrm{mg} \cdot \mathrm{m}^{-3}$ of chlorophyll a), as typically observed in surface waters newcomers, it becomes abundant in the mass transport of water when is the elapsed time required for the multiplication of cells $(>1.5$ mg. $\mathrm{m}^{-3}$ of chlorophyll between San Pedro and Abidjan).
In Ghana, high chlorophyll concentrations are observed at the mouths of the Volta. However Sevrin Reyssac (1993) noted that upwelling of the great cold season which causes the largest enrichment of surface waters in the year has its effect amplified by the terrigenous input resulting from the flooding rivers. It stressed that during this season, is most intense development of phytoplankton in the year, although the latter is interrupted by short phases of decline. Our results are consistent with this author in that it draws the conclusion that the chlorophyll maximum occurs near the coast. High phytoplankton concentrations and low temperatures observed in the headlands (Cape Palmas and Cape Three Points) are also attributed to the effect of the Guinea Current, which creates a cyclonic eddy permanently renewing the water in these different locations (Pezennec et al., 1993). The surface waters resurgence, cold and rich, are driven to the east; which warms up and causes a depletion of the waters around Cape Palmas. We also noted that the intensity of the 
annual and interannual upwelling is very high in Ghana and at low in Côte d'Ivoire, which is consistent with the results of Arfi et al. (1993). Indeed, studies by these authors on "the influence of a spatiotemporal index characterizing the strength of the resurgence of the Ivorian-Ghanaian coast" showed that the intensities calculated for the large seasonal cold season are high on entire coastline.

All this shows that chlorophyll concentration develops in most cases parallel to the change in the upwelling intensity on the entire Ivorian-Ghanaian coastline. Indeed, when the upwelling intensity is high, the chlorophyll concentration is high, and when the intensity is low, the chlorophyll concentration is also low. This relationship is often modulated by exceptional behavior. However, it is on the Ivorian continental shelf as the largest amount of chlorophyll concentration is observed. That is to say that this environment would be more productive than that of Ghana (Djagoua et al., in edition) despite the low upwelling intensity observed. The relationship between the content of nutrients and, on one hand with the temperature and the other with the chlorophyll concentration on the Continental Shelf of Côte d'Ivoire show that during the cold season, the upwelling enriches euphotic zone of the ocean nutrients that have an immediate impact on production whose primary biological growth in the chlorophyll concentration is driven by an increase in content of nutrients necessary for their photosynthetic activity (Herbland et Le Loeuff, 1993, Arfi et al. 2002; Koranteng and McGlade, 2002). John et al. (2002) analyzed phytoplankton concentrations from December 1995 to April 1999 using "Continuous Plankton Recorder (CPR)" data to assess the variability in the coastal area between Cape Palmas and Nigeria. The information collected in this area using the CPR for the period 1998-1999 appear to be consistent with satellite observations, indicating a decrease in chlorophyll concentrations from west to east. Suggesting that high intensity of coastal upwelling inhibits the activity of phytoplankton chlorophyll, reducing chlorophyll concentrations on the continental shelf of Ghana (Demarcq and Faure, 1998).

\section{CONCLUSION}

Comparative analysis of indices of upwelling and productive habitat shows that although the upwelling ecosystem in Ghana is more intense, it is not very productive as that of Côte d'Ivoire, whose waters are warmer. Analysis by classical models of relationships between variables $\mathrm{CHL}$, SST and nutrients can't demonstrate clearly the relationship between these variables, except in Côte d'Ivoire, where the relationship between nutrients and SST is clear. Hence the transformation of variables by non-linear regression, which showed that correlations remain linear and growing [CHL] and decreasing for the relationship (PO2 + NO3) in Côte d'Ivoire. This shows that all variables in Ivorian waters are correlated linearly. Unlike Ghana, where the relationships have a dish with a hollow point. This suggests that fluctuations in the intensity of upwelling would limit the availability of nutrients necessary for the development of phytoplankton.

\section{ACKNOWLEDGEMENTS}

The authors wish to thank the "Physical oceanography DAAC" for the Sea Surface Temperature data and "GIOVANNI" for the SeawiFS chlorophyll concentration. The authors also express their gratitude to GOOS-Africa (Global Ocean Observation) and GEM-GC Projects (Large Marine Ecosystem Project of the Guinea Current) and crosscutting of UNESCO for the support granted to this initiative.

\section{REFERENCES}

Arfi, R., Pezennec, O., Cissoko, S. et Mensah, M. (1991). Variation spatiale et temporelle de la résurgence ivoiro-ghanéenne. In: pêcheries ouest-africaines. Variabilité, instabilité et changement. Cury P., Roy C. eds., ORSTOM, Paris, 162-17.

Arfi, R., Bouvy, M. and Ménard, F. (2002). Environmental Variability at a coastal Station near Abidjan: Oceanic and Continental Influences. In The Gulf of Guinea Large Marine Ecosystem, J. M. McGlade, P. Cury, K. A. Koranteng and N. J. Hardmann-Mountford (Eds), 103-117, (Amsterdam, Elsevier).

Arfi, R., Pezennec, O., Cissoko, S. et Mensah, M. (1993). Evolution temporelle d'un indice caractérisant l'intensité de la résurgence ivoiro-ghanéenne. In: Environnement et ressources Aquatiques de la Côte d'Ivoire. I- Le milieu marin, Paris ORSTOM, 111-122.

Bakun, A. (1978). Guinea Current Upwelling. Nature, vol. $271,147-150$.

Binet, D. (1983a). Phytoplancton et production primaire des régimes côtiers à upwelling saisonniers dans le golfe de Guinée. Océanographie Tropicale, vol.18, n², 231335.

Binet, D. (1983b). Zooplancton des régions côtières à upwellings saisonnières du golfe de Guinée. Océanographie Tropicale, vol.18, 357-380. 
Colin, C. (1988). Coastal upwelling events in front of the Ivory Coast during the FOCAL program. Oceanologica Acta, 11, 125-138.

Demarcq, H. and Faure, V. (1998). Coastal upwelling and associated retention indices derived from satellite SST. Application to Octopus vulgaris recruitment. Oceanologica Acta, vol. 23, n4, 391-408.

Djagoua, E. M. V. (2003). Contribution de l'imagerie satellitaire visible et infra rouge thermique à l'étude de la variabilité spatio-temporelle des phénomènes physiques de surface du littoral marin ivoirien et implication dans la variabilité du phytoplancton e des prises de Sardinella aurita. Thèse unique, Univ. Cocody (Côte d'Ivoire), 136p.

Djagoua, E. V., Larouche P., Kassi J. B.., Affian, K. et Saley, B. (2011). Variabilité saisonnière et interannuelle de la concentration de la chlorophylle dans la zone côtière du golfe de Guinée. En édition dans la revue International Journal of Remote Sensing, 32(14), pp. 3851 - 3874. DOI: 10.1080/01431161003782072.

Dufour, P. and Berland, B. (1999). Nutrient control of phytoplanktonic biomass in atoll lagoons and Pacific ocean waters: studies with factorial enrichment bioassays. Journal Exp. Mar. Biol. Ecol, vol. 234, n², 147-166.

Feldman, G. C. (1986). Variability of the productive habiat in the Eastern equatorial Pacific. EOS Trans. Am. Geophys. Union, Vol. $67 n^{\circ} 9,106-108$.

Hardman-Mountford, N. J. and McGlade, J. M. (2002a). Defining ecosystem structure from natural variability: Application of principal components analysis to remotely sensed SST. The gulf of Guinea large Marine Ecosystem, J. M. McGlade, P. Cury, K. A Koranteng and Hardman-Mountford (editors), 67-82.

Herbland A. et Le Loeuff P. (1993). Les sels nutritifs au large de la Côte d'Ivoire. . In: Environnement et ressources Aquatiques de la Côte d'Ivoire. I- Le milieu marin, Paris ORSTOM, 123-148.

Ingham, M.C. (1970). Coastal upwelling in the Northwestern gulf of Guinea. Bull. Mari. Sci., 20, 1-34.

John, A. W. G., Reid, P. C., Batten, S. D. and Anang, E. R. (2002). Monitoring Levels of "phytoplankton colour" in the Gulfe of Guinea Using Ships of Opportunity. In The Gulf of Guinea Large Marine Ecosystem, J. M. McGlade, P. Cury, K. A. Koranteng and N. J. Hardmann-Mountford (Eds), 141-146, (Amsterdam, Elsevier).

Koranteng, K. A. and McGlade, J. M. (2002). PhysicoChemical Changes in Continental Shelf Waters of the Gulf of Guinea and possible Impacts on resource variability. In The Gulf of Guinea Large Marine Ecosystem, J. M. McGlade, P. Cury, K. A. Koranteng and N. J. Hardmann-Mountford (Eds), 93-102, (Amsterdam, Elsevier).

Marchal, E. et Picaut, J. (1977). Répartition et abondance évaluées par écho-intégration des poissons du plateau ivoiro-ghanéen en relation avec les upwellings locaux. Journal de Recherche Oceanographique, 2, 39-57.

Morlière, A. (1970). Les saisons marines devant Abidjan. Document Scientifique du Centre de Recherche Océanographique d'Abidjan, 1, 1-15.

Pezennec, O., Marchal, E; et Bard, F. X. (1993). Les espèces pélagiques côtières en côte d'Ivoire: Ressources et exploitation. . In: Environnement et ressources Aquatiques de la Côte d'Ivoire. I- Le milieu marin, Paris ORSTOM, 387-426.

Sevrin-Reyssac, J. (1993). Phytoplancton et production primaire dans les eaux marines ivoiriennes. In Environnement et Ressources Aquatiques de la Côte d'Ivoire. I-Le milieu marin, Paris, ORSTOM, 151-166.

Sherman, K., Alexander, L. M. and Gold, B. D. (1991). Food chains, yields, models and management of large marine ecosystems. Westview Press, 310p. 